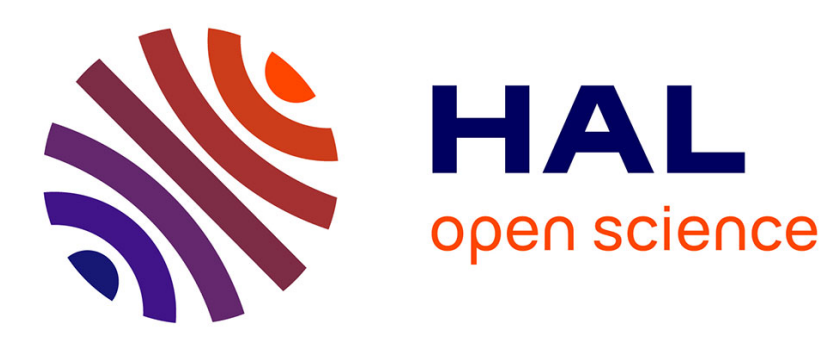

\title{
ELECTRON ACCUMULATION AT THE n-ZnSe/n-GaAs INTERFACE
}

K. Mazuruk, M. Benzaquen, D. Walsh

\section{To cite this version:}

K. Mazuruk, M. Benzaquen, D. Walsh. ELECTRON ACCUMULATION AT THE nZnSe/n-GaAs INTERFACE. Journal de Physique Colloques, 1987, 48 (C5), pp.C5-357-C5-361. 10.1051/jphyscol:1987577 . jpa-00226781

\section{HAL Id: jpa-00226781 https://hal.science/jpa-00226781}

Submitted on 1 Jan 1987

HAL is a multi-disciplinary open access archive for the deposit and dissemination of scientific research documents, whether they are published or not. The documents may come from teaching and research institutions in France or abroad, or from public or private research centers.
L'archive ouverte pluridisciplinaire HAL, est destinée au dépôt et à la diffusion de documents scientifiques de niveau recherche, publiés ou non, émanant des établissements d'enseignement et de recherche français ou étrangers, des laboratoires publics ou privés. 


\title{
ELECTRON ACCUMULATION AT THE n-ZnSe/n-GaAs INTERFACE
}

\author{
K. MAZURUK, M. BENZAQUEN and D. WALSH \\ Physics Department, MCGill University, 3600 University Street. \\ Montreal, $P Q, H 3 A 2 T 8$, Canada
}

\section{SOYMATRB}

Des résultats soutenant la présence d'une couche d'accumulation électronique dans le $\mathrm{ZnSe}$, a l'interface de l'hétérostructure n-ZnSe/n-GaAs, sont présentés. Une couche tampon de GaAs de type $\mathrm{n}$, de $1 \mu \mathrm{m}$ d'épaisseur, avec une concentration électronique initiale de l'ordre de $10^{15} \mathrm{~cm}^{-3}$, que 1 'on a fait crô̂tre sur un substrat semi-isolant de GaAs d'orientation (100), se trouve être totalement vidée de ses électrons lorsque l'on fait croŝtre sur elle une couche épitaxique de $\mathrm{znSe}$ de type $\mathrm{n}$. La concentration électronique de la couche tampon se trouve rétablie quand le znse est retiré par une attaque chimique sélective. La conductance correspondante à cette couche de ZnSe decroît logarithmiquement avec la temperature, passant à une conduction d'activation au-dessus de $6 \mathrm{~K}$, du fait d'une forte localisation. Ce comportement est caractéristique d'un système bi-dimensionnel.

\section{ABSTRACT}

Evidence for electron accumulation in the $\mathrm{ZnSe}$ side of $\mathrm{n}-\mathrm{ZnSe} / \mathrm{n}-\mathrm{GaAs}$ heterostructures is presented. An $n-G a A s$ buffer layer, approximately $1 \mu \mathrm{m}$ thick, grown with low $10^{15} \mathrm{~cm}^{-3}$ electronic concentration on a semi-insulating (100) GaAs substrate is fully depleted of electrons when an additional epilayer of $n$. ZnSe is grown on top of it. The n-GaAs epilayer electron concentration is restored when the ZnSe is removed by selective etching. The corresponding conductance of the $n-Z n S e$ decreases logarithmically with temperature, going over to activated conduction below $6 \mathrm{~K}$ due to strong localization, a characteristic of a 2-D system.

In recent years, the growth by both MOCVD and MBE of ZnSe on GaAs has resulted in a great improvement in the optical properties of ZnSe epitactic layers $^{1}$. For relatively thick lightly doped $\left(\mathrm{n} \sim 510^{16} \mathrm{~cm}^{-3}\right) \mathrm{n}$-ZnSe epilayers grown on semi-insulating (SI) GaAs substrates the transport properties are well understood: the conduction electron concentration is governed by thermal excitation from donor impurities, the corresponding mobility being considerably reduced by large compensation ${ }^{2}$. Nevertheless, when the transport properties are compared for different epilayer thickness $(t)$ in the submicron to micron range ${ }^{3}$, they are singularly unusual in that the average room $T$ resistivity of nominally 
undoped $n-Z n S e$ on SI GaAs increases with $t$. In addition, the usual free exciton photoluminescence ( $\mathrm{PL}$ ), which is at $2.8015 \mathrm{eV}$ for thick ZnSe samples, was found to be shifted to higher photon energy for submicron thick ZnSe grown by MBE, namely to $2.8054 \mathrm{eV}$ for ZnSe on GaAs substrates ${ }^{4}$ and $2.8064 \mathrm{eV}$ for ZnSe on a GaAs buffer layer 5 . The latter ${ }^{5}$ demonstrated by RHEED that nucleation of ZnSe on the GaAs epilayer proceeded by a 2-D growth mechanism and accounted for the 5 $m e V$ shift in PL by valence band splitting due to the uniform tetragonal lattice distortion. Recently, we have reported the electronic Raman spectrum of neutral acceptor impurities, identified as phosphorus in undoped compensated $n$-znse on a GaAs buffer, the non-equilibrium population being generated by below band-gap laser light ${ }^{6}$. This spectrum showed a $\Gamma_{8}$ ground state splitting of $52 \mathrm{~cm}^{-1}$ in agreement with deformation potential estimates for a uniform lattice distortion due to the $0.24 \%$ mismatch.

The ZnSe epitactic layers used in this study were deposited on (100) GaAs substrates by low pressure MOCVD using dimethylzinc and $\mathrm{H}_{2}$ Se diluted with $\mathrm{H}_{2}$ as source materials. At growth temperatures below $350^{\circ} \mathrm{C}$, highly resistive layers are observed, but at $400^{\circ} \mathrm{C}$ and above they are conducting. Assuming a uniform electron distribution across the epilayer, the electron concentration at room $T$ varied from $1.410^{18} \mathrm{~cm}^{-3}$ to $1.710^{17} \mathrm{~cm}^{-3}$ as $\mathrm{t}$ varied from $0.05 \mu \mathrm{m}$ to $0.55 \mu \mathrm{m}$ for a number of samples grown on SI GaAs at $400^{\circ} \mathrm{C}$ under identical conditions except for growth time. The results indicate the presence of a very conducting layer near the interface, the origin of which was examined in the following way. Two $1.1 \mu \mathrm{m}$ thick n-GaAs epilayers (samples 1 and 2) were grown simultaneously by MOCVD on two separate SI GaAs substrates $1 \mathrm{~cm}$ square, in the same reactor and under identical conditions. Subsequently, sample 1 was transferred in an inert ambient to another similar reactor where a $0.35 \mu \mathrm{m}$ thick $\mathrm{n} \cdot \mathrm{ZnSe}$ epilayer was grown on top of it. After removing $2 \mathrm{~mm}$ square of $\mathrm{ZnSe}$ from each of the four corners for electrical contacts to the underlying $n$-GaAs epilayer using alloyed tin dots, the GaAs epilayer was found by the Van Der Pauw technique to be completely depleted, although the electron concentration of the $n$-GaAs epilayer of sample 2 was $9.010^{14} \mathrm{~cm}^{-3}$. Furthermore, on removing additional $\mathrm{ZnSe}$ so that a $2 \mathrm{~mm}$ wide strip of GaAs was fully exposed between two contacts on one side of the sample, this GaAs strip became conducting, although the conductivity across the diagonal was zero. This indicates that electron depletion occurs on the GaAs side of the interface contrary to popular expectations 7,8 .

In addition, low $T$ conductivity measurements of the $n-Z n S e$ epilayer of sample 1 showed properties corresponding to a 2-D metallic system. Between 1.4 and $6 \mathrm{~K}$ the conduction is activated (Fig. 1), being given by

$$
\sigma=2.5910^{-4} \exp -\left[(107.7 / \mathrm{T})^{1 / 2}\right]
$$

which has been observed in quench-condensed metal films like $\mathrm{Au}$ and $\mathrm{Cu}^{9}$ and also $\mathrm{Si}$ inversion layers 10,11 . Above $6 \mathrm{~K}$ the conduction goes over continuously to a 
logarithmic dependence on $T$ as shown in Fig. 2. The conductance has the wellknown dependence :

$$
\sigma(T)=\sigma(\mathrm{To})+\frac{\alpha \mathrm{Pe}^{2}}{\pi \mathrm{h}} \ln (\mathrm{T} / \mathrm{To})
$$

where $\sigma(T o)=1.3310^{-5} \Omega^{-1}$, To $=18 \mathrm{~K}$ and $\alpha \mathrm{P}=0.87$. The deviation in Fig. 2 at high $T$ results from excitation to the conduction band from neutral donor impurities in the bulk $\mathrm{ZnSe}$. The corresponding conductance is :

$$
\sigma^{\prime}=\sigma_{c} \exp -\left[\left(E_{c}-E_{F}\right) / K_{B} T\right]
$$

where $\sigma_{c}=2.2810^{-5} \Omega^{-1}$ and $E_{c}-E_{F}=14.06 \mathrm{meV}, K_{B}$ being the Boltzmann constant. This energy is approximately half the shallow donor binding energy in $\mathrm{ZnSe}^{1}$ as expected for a compensated crystal in this $T$ range, where $N_{D}>n>N_{A}$. We note that $\sigma($ To $)$ is close to the minimum metallic value $e^{2} / \pi_{h}=1.2310^{-5} \Omega^{-1}$. This system, which differs essentially from the GaAs/GaAlAs heterostructure, has

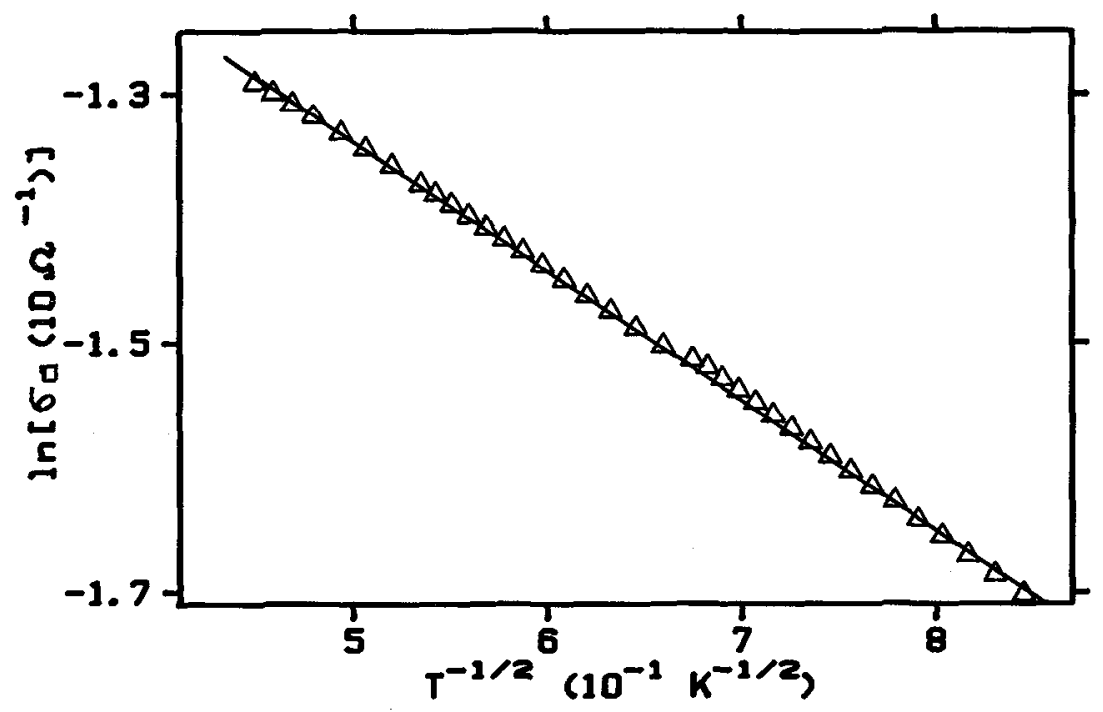

Fig. 1 In[ $\sigma(T)]$ Vs. $T^{-12}=$ between 1.4 and $6 K$

considerable disorder due to impurity compensation and interfacial nonuniformity, but does have similar transport properties to that observed in doping-modulated GaAs superlattices ${ }^{12}$. Moreover, the n-ZnSe/n-GaAs heterostructure on a SI GaAs substrate with conducting $\mathrm{ZnSe}$ as gate has FET characteristics. Photoconductivity of the $\mathrm{n}-\mathrm{znSe}$ layer grown on $\mathrm{n}-\mathrm{GaAs}$ was measured at $7 \mathrm{~K}$ using below ZnSe band-gap illumination $(6828 \mathrm{~nm})$. A logarithmic decrease of resistivity with light intensity was obtained, and was inconclusive 
due perhaps to electron excitation from deep electron-trap levels in the ZnSe.

In conclusion we have shown some evidence which indicates that for a $n$. $\mathrm{ZnSe} / \mathrm{n}$-GaAs heterostructure, electron accumulation occurs on the ZnSe side due presumably to the polarization change at the interface. Indeed, exploratory $n$ $\mathrm{ZnSe} / \mathrm{n}-\mathrm{GaAs} / \mathrm{n}^{+}$-GaAs heterojunctions showed a $0.8 \mathrm{~V}$ photovoltage, with the GaAs side negative, consistent with GaAs depletion. The results are consistent with the self-consistent pseudo-potential of Ihm and Cohen ${ }^{13}$ for (100) $\mathrm{ZnSe} / \mathrm{GaAs}$ interface. The conductance of the $n$-ZnSe decreased logarithmically with $T$ going over to activated conduction at $6 \mathrm{k}$ due to strong localization, a characteristic of a 2-D metallic system. Zn diffusion in GaAs does not appear to be a problem during the MOCVD growth, Znse being readily formed at the GaAs surface.

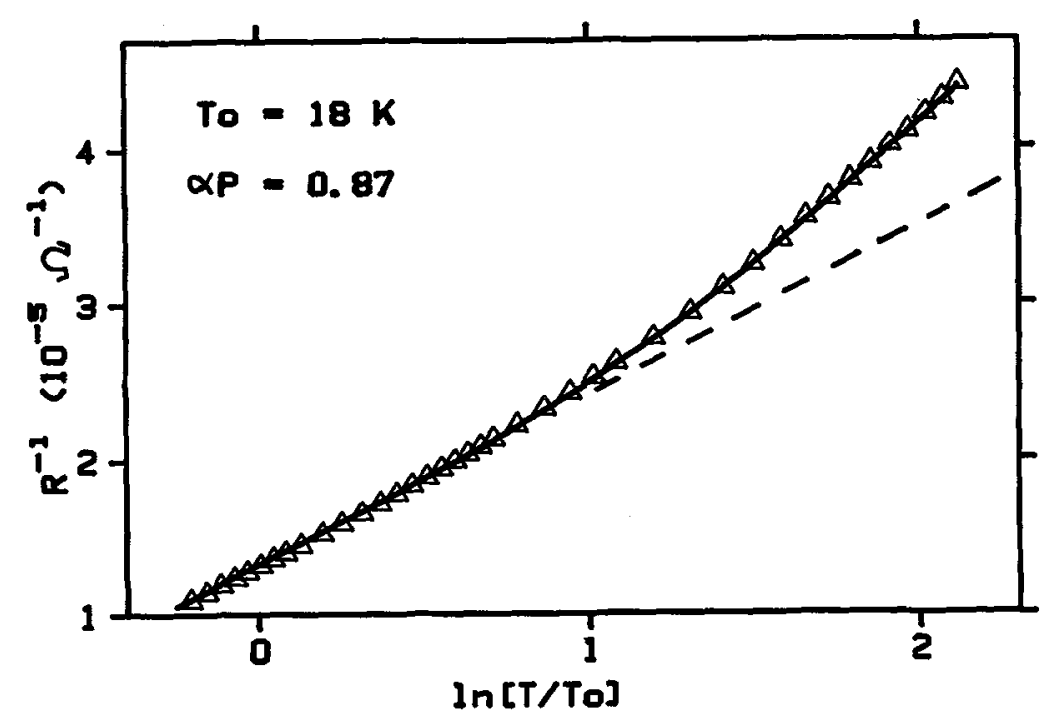

Fig.2 $\sigma(T)$ vs. In(T/To) between 10 and $150 \mathrm{~K}$

\section{REFERENCES}

1. P.J. Dean, W. Stutius, G.F. Newmark, B.J. Fitzpatrick and R.N. Bhargava, Phys. Rev. B 27,2419 (1983)

2. W. Stutius, J. Appl. Phys. 53, 284 (1982).

3. A. Yoshikawa, S. Yamega, K. Taneka and H. Kasai, J. Cryst. Growth 72,13 (1985).

4. Takafumi Yao, Toshihiko Takela and Ryuji Watanuki, Appl. Phys. Lett. 48 , 1615 (1986).

5. R.L. Gunshor, LA. Kolodziejski, M.R. Malloch, M. Vaziri, C. Choi and N. Otsuka, AppI. Phys. Lett. 으, 200 (1987). 
6. D. Walsh, K. Mazuruk and M. Benzaquen, Phys. Rev. B $\underline{30}$, (to be published August 15, 1987).

7. H. Kroemer, Proceedings of the NATO Advanced Study Institute on Molecular Beam Epitaxy and Heterostructures, Erice, Sicily, 1983, Ed. by L.L. Chang and K. Ploog (M. Nijhoff, The Netherlands 1984).

8. J. Tersoff, Phys. Rev. Lett. 56, 2755 (1986).

9. R.C. Dynes, J.P. Garno and J.M. Rowell, Phys. Rev. Lett. 40, 479 (1978).

10. S.J. Allen Jr., D.C. Tsui and F. DeRosa, Phys. Rev. Lett. 35, 1359 (1975).

11. R.C. Dynes, Surface Science 113,510 (1982).

12. T.H. Englert, J.C. Mann, G. Remenyi, H. Kunzel, K. Ploog and A. Fisher, Surface Science $\underline{142}, 68$ (1984)

13. J. Ihm and M.L. Cohen, Phys. Rev. B 20,729 (1979) 